\title{
China's cultural fundamentals behind current foreign policy views: Heritage of old thinking habits in Chinese modern thoughts
}

\author{
Milan Lajčiak \\ Ambassador of the Slovak Republic to the Republic of Korea \\ Slovak. Embassy in Seoul, South Korea \\ Email:milan.lajciak@gmail.com
}

\begin{abstract}
Different philosophical frameworks between China and the West found their reflection in diverging concepts of managing relations with the outside world. China focused more on circumstances, managing situation and preventing conflicts, the West was resolution oriented, aimed at fighting opponents and looking for victory in conflicts. China has introduced the idea of harmonyhierarchy world, while the West, on the opposite, tends to freedom-conflict patterns of relations. On China's side, thinking habits and old thought paradigms of statecraft are until now deeply ingrained in mentality, thus shaping China's policy today. Understanding the background of Chinese traditional thinking modes and mind heritage helps better understanding of China's rise in global affairs as well as of Sino-American relations as the key element in a search for global leadership.
\end{abstract}

Keywords: China, West, thinking habits, foreign policy concepts, China rise, SinoAmerican relations.

JEL Classification: F5, P5, Z1

\section{INTRODUCTION}

Numerous comparative studies indicate that our present mindsets are marked by cultural fundamentals and influenced by traditional thinking patterns. Different cultures demonstrate different levels of embodiment of traditional thought paradigms in our modern times. When comparing the Confucian East and the West, these differences are vividly popping out, reflecting distinct historical paths and hierarchy of values. The most distinguishing and exceptional cultural heritage among East Asian countries has been attributed undoubtedly to China.

With China's overwhelming economic growth, political ambitions and active diplomacy that has been showing remarkable different perspectives from Western countries, the increasing attention is drawn to Chinese perspectives of inter-state relations. As a consequence, debates are centered on China's concepts and ideas of reshaping future global architecture. It is hard to obtain a complex explanation of these 
questions only from the most obvious economic and geopolitical points of view alone. One needs an understanding of Chinese core values and worldviews which stem from Chinese philosophy.

There is sufficient research on various ancient Chinese schools of philosophy concerning moral notions, domestic governance and international relations. This study discusses similarities and differences between China's and Western philosophical traditions and concepts, related to interstate order and examines the influence of ancient Chinese thought paradigms on contemporary Chinese policy-makers in approaching global affairs. Attention in this regard is focused on understanding Chinese ideas of harmonious-hierarchical world, Eastern and Western analogies in realpolitik and strategies of war as well as rejuvenating narratives of Chinese leaders in their attempts to restore China's power status among the central position in the world politics. The study illuminates relevant as well as non-relevant aspects of Chinese ancient concepts of managing inter-states relations in the $21^{\text {st }}$ century and in a search of global leadership analyses the future of Sino-American relations as the key factor in shaping architecture of international relations.

The main idea of the study is that thinking habits and old thought paradigms of statecraft are so deeply ingrained in Chinese mentality that they are still shaping China's policy today. Illuminating the philosophical background and linkage between the old concepts and today's thinking inclinations among Chinese leaders and Chinese leading academicians the study contributes to better understanding of China's rise and her ambitions in global affairs.

\section{CHINESE AND WESTERN START-UPS OF INTER-STATE RELATIONS}

Generally, China's main concept of dealing with outside world stemmed from the philosophical framework of the harmonious and hierarchical Universe. Based on the feeling of China's cultural superiority over neighbors, China put herself on the top of the hierarchical world order with other countries in vassal positions as well as tributes duties. Chinese main concepts of international relations have been developed out of cultural fundamentals of Daoism, Confucianism and Mohism that were teaching the primordial nature of ethics over law in human society. Against this trend, in the $3^{\text {rd }}$ century BC during the period of cruelty, chaos, permanent wars of all against all, the Legalist School (Han Feizl) argued that the law as the instrument of statecraft is more efficient than ethics. Legalists played a pivotal role in achieving the first Chinese unified empire that became reality after the long period of $W$ arring States $(475-221$ BC), that needed a strong ruler and draconian laws to make order. They refused ethical values as the prime principle for governance and emphasized dominant psychological and physical power, pitiless statecraft and power of law. In a matter of decades, historical events reversed this starting trend and shortly after the creation of the first Chinese Empire Legalist arguments of the law-over-ethics lost their power in favor of the concept of the ethics-over-law of Confucianism and Daoism. From the Song Dynasty of $11^{\text {th }}$ century Confucian realistic branch of Master Xunzi (310 - 219 B.C.) who advocated that human character is from the nature "bad", yielded to the idealistic branch of Confucianism of Master Mencius (391 - 308 B.C.) advocating that human predisposition is naturally "good". This concept has prevailed as major stream of Confucian interpretations, with heavily ethical perspective until today, focusing on upholding harmonious relations of intra-society as well as in inter-state world.

In the West, most western textbooks related to relations among countries begin with ancient Greece and Rome, advance through the European Middle Ages, and continue with the Peace ofWestphalia (1648) and the period of Enligbtenment. It was only after the emergence of nation-states in the wake of the so called Thirty Years' War (1618-1648) that thoughts of models of international relations began to appear on the Western intellectual horizon. Before this period the Western history of international relations was based on conquest and expansion rather than on management. Treaty of Westphalia is considered in a traditional view 
as a historical watershed in Western hemisphere due to building model of international relations based on the principle of territorial integrity of states (later nation-states) that underlines the modern international system. State sovereignty over territory and domestic affairs started to be accepted as a principle of international law. As European influence spread across the globe, principles of Westphalia system have become central to international law and to the prevailing world order. In other words, in Western thinking, prior to the $17^{\text {th }}$ century, the notion of management of conflict situations with regard to international relations was hardly mentioned, unlike Chinese thinkers.

As to the West - East relations, the West started to acknowledge more deeply non-Western societies only during the nineteenth and twentieth centuries. Even then the Western mind was viewing Asia through the prism of power and cultural dominance within the context of colonization, rather than as international actor with foreign policy objectives or value in their own right.

It is also necessary to notice, that one can find certain analogies between the West and the East in managing inter-state relations and strong similarities in realpolitik approaches between the Legalist School in China and Machiavelli's art of statecraft in the West, as well as in strategies of waging a war, though the time gap between these concepts is over 2000 years.

\section{PHILOSOPHICAL BACKGROUND OF ANCIENT INTERNATIONAL ORDER CONCEPTS}

There are several diverging philosophical concepts and cultural fundamentals between the West and Confucian East that have historically subscribed into forming attitudes of these different parts of the world in viewing the outside world. In case of the Confucian East the main incubator of thinking paradigms was China.

Different philosophical approaches were manifested in different Chinese and Western conceptual attitudes in dealing with the outside world. They can be found, to mention at least some of them, in concepts such as complementarity versus dichotomy, transformation versus teleology, management versus resolution, preemption of conflicts versus victory in conflicts, focus on circumstances versus focus on opponents, mode of action by default versus mode of action by design, focus on consequences versus focus on goals, perception of conceptualization versus perception of specific issues, viewing the world as a chart of harmony versus the world of liberty as well as looking for harmony in diversity versus unity in diversity.

Among above mentioned concepts, the study elaborates on those that prove to have certain relevance in forming ancient approaches of managing inter-state affairs.

\subsection{Harmony and hierarchy as core values in managing relations}

The core value of Chinese traditional culture as far as society as well inter-state relations are concerned is the concept of harmony and the concept of hierarchical order of Universe. Harmony (Hexie) is, in fact, a complete ideological system that consists not only of values but also a philosophy with its own world outlook. Concept of harmony includes principles such as the Tai Chi philosophy and the yin-yang dialectics that help people understand the origins of human beings and the evolution of society as well as relations of man and nature, among human beings and connectivity between mind and soul.

Idea of harmony is connected with an idea of hierarchical order of the Universe that is reflected in all its conceptual derivatives including human society and inter-society interaction. Based on these principles, ancient Chinese sages have created ideological system that sought to attain a harmonious equilibrium in the 
world based on vertical structure ${ }^{1}$ where every person had to identify him/herself with his/her social role in the society as well as every state had to accept it's subordinate position to China as the center of Universe and to respect this kind of structural relations as a natural order.

In China, the prevailing stress on managing harmonious relations through appropriate organizational models of society caused the lack of social dynamism and resulted into very stable but passive society without major changes of socio-economic system for two millennia. Maintaining harmony went at the expense of the respect of human individual rights that were ignored for the sake of effective functioning of the "whole". In contrast, Western societies, based on individualism, remained open, expansive and very vibrant in social advancement. When confrontation between the West and the East appeared, the latter one was destined to be eclipsed by the former one.

\subsection{Perceptions of opposites and opponents}

In Chinese view, there is a dynamic inherent in the universe that converts imbalance into balance, incoordination to coordination, and disequilibrium into equilibrium. This dynamic manifests itself through the interaction of opposites (opposite poles) as they struggle but also cooperate with each another. Through interaction of these "poles" the Universe has come to motion and through this principle the whole nature as well as social domain is functioning.

Chinese perception of opposites stems from Daoism and interpretation of yin-yang principles. In difference to the Western thinking, there is a different interpretation of the functioning of these "opposites" in the East. Opposite particles are considered, in addition to their contrasting character, also as elements mutually dependent, complementing, conditioned and transforming into each other. Virtually, all East Asian schools of thoughts are associated directly or indirectly with this concept that implies mutual dependency and interconnectedness of the whole nature. This philosophical framework has also impacted Chinese attitudes of the man-man relationships as well as viewing opponents and outside world.

The main concern of Chinese thinkers was looking for a "Way" (Dao) how to abide by these principles in order to promote coexistence of numerous contrasting elements. Managing and upholding harmonious relations was the core of their endeavors. The viewing the opposites/opponents/enemies as complement and mutually conditioned/transforming elements rather than irreconcilably conflicting subjects, has subscribed to the Chinese tendency to view the situation in a complex way, focusing more on upholding interaction lines among the subjects rather than on subjects themselves. In other words, Chinese minds were attracted by the mastership of managing relationships and situations rather than by eliminating opponents. In this way, the "managing approach" represented the foundation of East Asian thought in crisis situations.

In contrast, Western culture, starting from Greeks, acquired a dichotomous logic of separation of opposite elements viewing them not only as contrasting but predominantly as conflicting in their nature. It is true that one can find in Heraclitus school of thoughts similar approach to the Eastern mind but it has never become the centerpiece of Western thinking. In opposite, it was Pythagoras who infused the West with the idea of soul, existing independently of the body, and representing the absolute "being" of the universe. The concept of eternal soul further influenced Plato and Aristotle and subsequently became the pillar of the Western though system. Later, Greek idea of soul and Judeo-Christian concept of spirit merged

\footnotetext{
${ }^{1}$ Zhang Lihua (2013). China's Traditional V alues and Moderen Foreign Policy. Carnegie - Tsinghua. Center for Global Policy.
} 
together. The dichotomy of physical and spiritual world, as a reflection of the division between "opposites", was further supported during Renaissance period by R. Descart and his dualistic approach to the body and mind. As a result, perception of opposites as separated elements in Western thinking contributed into the ignorance of connectivity and of mutual dependency of opposing subjects. In social context the opponent/enemy was approached as a conflicting rather than complementing element with the ambition of annihilating him rather than assimilating or transforming. That is why the Western thinking inclined to focus more on fighting the opponents rather than managing situations to avoid conflicts.

In more general terms, the West was focusing more on goal oriented actions and conflict solutions opposite to Chinese approach that was focusing on circumstances and managing the permanently transforming environment.

\subsection{Management of situation rather than conflict resolution}

Management is situation oriented, whereas resolution is problem oriented approach. The notion of harmony led China to focus on circumstances and to manage situations with the aim not to allow looming crisis to get out of control. On the other hand, the West with its emphasis on liberty and individuality "allowed" popping out many conflicts that led the West to focus on specific problems and conflict solutions.

In China's notion, the emergence of conflicts or wars, in difference to the West, meant the failure of management in its initial stage and the failure to take care of the situation accordingly prior the moment the conflict burst out. Consequently, the victory in war was considered in China only a part of the bigger "whole" and the ultimate goal was the preemption of conflicts rather than victory in conflicts. The Western emphasis on resolution of the conflicts required clearly defined problem to be achieved by determined and decisive action. The victory in the conflict signified such an end of a problem. Western history demonstrates this attitude by emphasizing acts of heroism, glorification of victory and vanquishing of enemies on the battlefield. Heroes from Alexander to Caesar, Charlemagne, Napoleon and Conquistadors - all of them confirm this trend.

As a result, China became management oriented and the West resolution oriented culture. This in turn brought both cultures to posit contrasting aims toward inter-state relations. Chinese approach underlined the importance of premption of conflict, bearing in mind consequences of conflicts whereas the West stressed the urgency of victory in solution of conflicts as the ultimate goal of the process of resolution. This represented different objectives in thinking inclinations as well as in efforts. Chinese mind focused on circumstances whereas Western mind placed focus on opponents. ${ }^{2}$

Cultural differences between China and the West were reflected also in application of the "Golden Rule" in managing situations as well as solving conflicts. Chinese wisdom Do not do unto others as you do not want to have others do unto you (Analects. 15:24) is a different mode than Western Do to others what you want them to do to you (Matthew 7:12, Luke 6:31) though both wordings pursue the same intention. The former one is Confucian approach, representing passive noninterventionist attitude, the latter one is Christian approach, polar opposite, expressing active, proselytizing and more interventionist attitude.

${ }^{2}$ Choi, Y.J. (2015). East and West: Rise of East Asia and Fundamentals of Interantional Relations. P. 133 


\section{COMMON FEATURES OF "REALPOLITIK" IN THE EAST AND THE WEST}

It is difficult to find in the history of human thought two very similar political thinkers as Han Fei (280 - 233 B.C.) and Machiavelli (1469 - 1527) ${ }^{3}$. They lived in very different times, almost two millennia apart, but they both lived in times of permanent wars and chaos and both wanted to restore the order amid warfare that characterized their respective periods of time. In case of Han Fei, it was a period of Warring States in China, in case of Machiavelli there were contending city-states in Europe, constantly disturbing the peace and order of their worlds. They simply focused on maximum efficacy of the statecraft of the governing. In 19th century some of Western thinkers labeled Machiavelli's statecraft as realpolitik. Han Fei can also be put to this category of theories of statecraft. He was known as the central theorist of the School of Legalism in China with emphasis on law rather than ethics.

Han Fei neither Machiavelli used the term realpolitik but they shared the same basic orientation for maximizing methods of ruling society. They both described how humankind would behave from the standpoint of a ruler, dissociating humanity completely from the concept of ethics. With the aim of res toring the order they exhorted rulers to achieve effective measures. In case of Han Fei through the means of draconian laws and in case of Machiavelli with a complete disregard of ethics. They put overemphasis on realism in favor of efficacy. In their books Han Feizi (eponymous book of $\mathrm{Han} \mathrm{Fei} \mathrm{with} \mathrm{over} \mathrm{one} \mathrm{hundred}$ thousand words) and The Prince (Machiavelli's work of twenty six chapters) the common idea can be summed as "the rules of fair play do not apply in war". In the East, Han Feizi has been appreciated for its unwavering realism, in the West The Prince has epitomized the essence of realpolitik. The both enumerated similar elements of statecraft at the disposal of the ruler. Machiavelli picked the law, fox's cleverness and lion's power, Han Fei reckons law, shu and shi. The last two terms have no equivalent in Western culture though shu is close to the term method, manipulation, tact, craft and shi to the term authority, position, power. For Machiavelli the law was less of a fundamental principle and more of an instrument of realpolitik. For Han Fei the law served as a double purpose - tool of statecraft and good governance.

This paper argues that in a completely different era and cultural background, Machiavelli and Han Feizi adopted similar political design paradigm of realism and that there is amazing similarity across time and space between them. Their common point is in their political ideology of a deep concern for the political practice. There is no doubt that both political designs reflect distinct historical treatments and differences of economic, social, and cultural development of their respective countries and that after them China and Western countries took completely different political roads. But the comparison between Han Fei and Machiavelli reveals many common views that were reflected in the respective Eastern and Western Realpolitik.

\section{THE ART OF WARFARE IN THE EAST AND THE WEST}

When one thinks of the art of war and strategists, many names may come to mind such. Recalling the last World War II names as Patton, Rommel, Montgomery, Zhukov would certainly be mentioned in any conversation. Certainly Napoleon and Frederick the Great would be spoken of regarding wars of earlier times and Gaius Julius Caesar and Alexander the Great of Macedon of ancient times. The list of notable warriors from history would be endless but more than any individual there are two books that have

${ }^{3}$ Han Fei, \& Machiavelli (2012). Non-Moral Political Outlook Research Papers Center, Post Time. http:/ / thediplomat.com/2015/01/why-we-should-study-chinas-machiavelli/ 
influenced strongly the study of the conduct of wars, the work $O n$ War of Karl von Clausewitz in the West and the work The Art of War of Sun Tzu in the East.

The book The art of War is attributed do Sun Tzu who lived to the end of Spring Autumn period (770 479 B.C.) that preceded to the period of Warring States (475 - 221 B.C.). Sun Tzu's work is counted as one of the most important of the Seven Military Classics in China, utilizing even in current days of business strategies and management of interpersonal relations. Clausewitz's book $O n W a r$ is in many aspects its closestEuropean counterpart. The Prussian general and military theorist Karl von Clausewitz (1780 -1831) gained his military experience during Napoleon Wars of the early 19th century and is considered as one of the most influential Western strategic theoretician on warfare. ${ }^{4}$

While Sun Tzu and Clausewitz were separated in history by over two thousand years, they are both thoroughly studied and praised for their council on war fighting. They share many ideas but also diverging approaches.

Perhaps the most striking contrast between them is in their separate means in reaching the end of victory. Sun Tzu advocates that the best way to achieve victory is to do so without fighting at all. He declares that "to subdue the enemy without fighting is the acme of skill." 5 The preferred methods for success in these matters would be the use of diplomacy, propaganda, and secret agents. By undermining the enemy's plans and allies in this way, the need for actual battle became unnecessary for victory. Clausewitz would disagree. One of the key of Clausewitz's concepts was that of a center of gravity, attacking of the enemy's army, capitol, or ally, essentially whatever it is the main hub of his power. In Clausewitz's view the enemy's center of gravity is "the point which all our energies should be directed. "' So in contrast to Sun Tzu's idea of winning the victory without a fight, Clausewitz stresses the fight as the key to success. In Clausewitz's mind, the goal of the engagement was to destroy the enemy's army.

Another diverging area of these two war theorists is the notion of the predictability of a war. Sun Tzu's considers that a war is rather predictable event and even when it burst out one would be able to forecast which side will be victorious and which defeated. Clausewitz saw things very differently. Having been a soldier since his early teens, he knew firsthand the confusion of the battlefield. In his view, a commander may have the best laid plans, but the "fog" of the battlefield can "prevent the enemy from being seen in time, a gun from firing when it should, a report from reaching the commanding officer." He accounts on uncontrollable factors that render plans, often times, mostly useless.

Sun Tzu values political winning without military engagement and focuses on the day after the battle, on assimilation rather than annihilation of the enemy. In this way Sun Tzu regards the enemy as a possible later ally and he considers how to subjugate and assimilate the enemy's army without its annihilation. Clausewitz, on the other hand, treats the enemy as a permanent opponent to be utterly annihilated. Sun Tzu prefers a war of strategy Clausewitz prefers a decisive war of annihilation. Both Sun Tzu and Clausewitz are motivated by the principle of self-preservation in their own environment. The difference between them is in their focus on the methods of achieving their goals.

${ }^{4}$ Ando (2008). Clausewith vs Sun Tzu. Past Tense

${ }^{5}$ Sun Tzu. Art of War. Full text. Translated by Lionel Giles

${ }^{6}$ Clausewitz. On War, excerpts relating to term "Center[s] of Gravity 


\section{MANAGING OF THE $21^{\mathrm{ST}}$ CENTURY GLOBAL CHALLENGES}

Contemporary world politics is necessary to be treated as a dynamic whole with issues that have become central in international politics. Specific attention should deserve pressing issues, such as failed states, civil wars, terrorism, territorial disputes, historical sentiments, securitized development, peacebuilding efforts, global resistance movements, politics of migration, global health and the environment to enumerate at least some of them. The scale of challenges will require cooperation of international community with mobilization all effective tools for managing situations in order to water down tensions and to prevent conflicts.

\subsection{Context of international relations in $21^{\text {st }}$ century}

The frequency of changes is rapidly growing, unpredictability becomes the norm of international relations and the management of diversity of tensions and situations is becoming the imperative of the day more than before. Based on Eastern yin-yang concept, the world has been turning from yang approaches with expansive features into the context of challenges with yin approaches requesting managing attitudes that are becoming more relevant in $21^{\text {st }}$ century environment. ${ }^{7}$

The world is becoming more multipolar than of one power dominated; much more about expanding influence through smart power with growing scale of soft cultural and economic elements than only military hardware; more about the power for deterrence than using power in military conflicts; and more about cooperation of international community for managing global problems that are impossible to be solved in capacity of a single country. That should be manifested by power of persuasion as opposed to the power of enforcement. In other words, "pen instead of sward" should be on agenda and the preventive diplomacy together with post-conflict management should be more in focus of international politics to create political environment that would be less of the need for conflicts solutions.

This is not to say that the world will be free of tensions, skirmishes, disputes, conflicts or even wars but it is to argue that the world is becoming one big village interconnected through globalization that will need more than ever the managerial than conquistador eyes. It is, among others, also due to the fact that political environment of the $21^{\text {st }}$ century has become more circumscribed in geographical terms and territorially settled as opposed to expansive and land conquering opportunities of the past. Colonial age ended and the evolving international environment dictates nations to compete with economic prowess rather than military might as they have done for millennia. Naked plundering and habitual raids cease to be preferred as methods of the self-preservation that is giving the international landscape the new paradigm of behavior.

The world has started to compete for economic clout through trade, technological superiority and influence of culture and is more interdependent, technology based and value oriented.

\subsection{Growing pressure for management of situations}

Western countries, during the "Arab Spring" that began in December 2010 in Tunisia, were strongly oriented to the support of democratic movements with the goal of dispose of dictatorial regimes. One of defining moments came in October 2011 with the death of Libyan leader Muammar Gaddafi. In both cases USA and allies achieved the goal to defeat dictatorial regimes but it appeared that not enough attention was

\footnotetext{
${ }^{7}$ Choi, Y.J. (2015). East and West: Rise of east Asia and Fundamentals of Interantional Relations. P. 128.
} 
paid to the after-conflict consequences that evolved into uncontrollable anarchy across the region. The Islamic State of Iraq and the Levant (ISIL) have become one of the main consequences of this situation and the cause of enormous problems in Syria and the Middle East.

Civil conflicts caused by ethnic, religious and cultural differences have emerged as major security concerns. Syria, Iraq, Yemen, Somalia, Bosnia, Rwanda, Angola, Serbia/Kosovo, East Timor, Sierra Leone, Sudan and South Sudan, Democratic Republic of Congo, Cote d'Ivoire, Central African Republic, to name at least some among others. Managing these conflicts has become the new task of international community. UN peacekeeping forces represent particular mechanism that to a certain extent suits for dealing with these problems but not in substantial scale. Africa is a continent that needs special attention to manage conflicts prior their outburst that impacts multiple domains. The gravity of African problems is serious and it is reflected actually by the fact that around eighty percent of resources of all UN peace-keeping operations are going to Africa.

Phenomena of refugees and displaced persons, massive immigration waves that started in 2015 from conflict-ridden areas in Syria and Northern Africa to the Europe is another symptom of the failure of these countries as well as of international community to manage the crisis situation. Continuation of migration waves clearly show the need to address the cause of problems prior the crisis reach the critical stage, otherwise conflict solution approach will be not in capacity to deal with these issues itself.

North Korea represents growing nuclear threat. Reclusive country is building nuclear and ballistic arsenal despite numerous UN SC resolutions and appeals of international community. Military conflict with North Korea is not conceivable, intervention would have disastrous consequences on the whole region, sanction regimes are not effective, international community appeals are ignored, the conflict seems to be frozen and the only chance is to focus on management of the tension, using creative preventive diplomacy and incorporating broader scale of elements into the management of the situation to avoid the military conflict.

Asymmetric threats, growing scale of terrorism, flow of illegal arms, proliferation of small and light arms, nuclear weapons, persistent threat of landmines, drug trafficking, cyber-attacks and skirmishes of unsettled territorial disputes represent numerous challenges for the global world. Enormous scale of threats is the reason why the West and the East will be under the pressure to focus on cooperation and looking for effective managing methods rather than allowing conflicts to be burst out.

\section{CHINESE MIND HERITAGE IN $21^{\text {ST }}$ CENTURY'S GLOBAL AFFAIRS}

Reviewing Chinese and Western cultural fundamentals relevant to outside world one can find different ancient paradigms of thinking that are resulting from basic philosophical frameworks in man - nature and man - man relationships. On Chinese side it was focus on the way how to keep and manage harmonious relations on the backdrop of hierarchical structure not allowing situation to burst into conflict while on the Western side it was the focus on effective solutions of bursting conflicts as the "end of the game".

Chinese mind was inclined to take into account broader context of situation and viewed the conflict as the result of the failing management of keeping harmonious relationship. Western mind was inclined to elaborate on solution methods of coming conflicts that were imminent from every corner. In China, there was a social imperative of supporting harmonious set-up "under the heaven" that found its manifestation in intra-society as well as in inter-state relationships with hierarchical order. Circumscribed geographical environment limited China's operational behavior, stable and harmonious world was its objective, management of the relations was the mechanism of achieving this goal. The crucial factor with regard to 
neighbors was Chinese cultural supremacy that has allowed infusion of hierarchical doctrine of relations. Combination of these factors enforced the model of situation management rather than conflict solutions.

In terms of international relations, harmony in East Asia in the past came at the price of the hierarchical order with other nations involved. Eastern harmony system was conditioned by hierarchy subordination system and represented Eastern harmony-hierarchy pattern of relations. The Western system opposed the Eastern one due to the rebellion nature that was favoring expansion and freedom through dangerous and costly conflicts. That created Western freedom-conflict pattern of relations. Both concepts had the same objective to dominate over others though with their conceptual differences. The West has become accustomed to notice the lack of freedom in the East, whereas the East points at the lack of harmony and responsibility.

Chinese heritage that would be relevant to address the $21^{\text {st }}$ century world politics is definitely more on a philosophic side of understanding transforming character of the nature rather than on harmony-hierarchy pattern of international relations that is unacceptable concept of modern world. Worldview perception of ever transforming processes, focus on broader context of conflicting situations rather than narrow oriented goals, applying moderation behavior instead of aggressiveness, paying a proper respect to different cultural fundamentals instead of looking for uniformity, giving appropriate time to evolution processes as well as respecting sovereignty represent those approaches that can infuse more perspectives into managing approaches. This kind of heritage matches the Western modern concept of preventive diplomacy and postconflict management and when being at a par with acknowledging universal human rights, it would be reasonably contributing into the broad perceptions of conflict resolutions. Here one can find relevancy of China's thinking paradigms in the modern times.

\section{UNITY IN DIVERSITY OR HARMONY IN DIVERSITY}

United Nations motto "unity in diversity" as an integrative approach to intercultural relations has been aimed at advocating liberalism and multiculturalism of the world, seeking to celebrate how a world can be stronger be welcoming different cultural, social and ethnic elements. It has been suggesting that far from being weakened by different cultural strands, a nation/group can be made stronger by acceptance of the many different contributions made by its constituent parts. This motto goes beyond mere tolerance of other ethnic, cultural and religious divisions by promoting the idea that each distinct constituent part plays a valid contribution which strengthens the whole.

The point is that some Asian countries led by China saw in "unity in diversity" the hidden agenda of the West to clinching and institutionalizing Western liberal values and raising the focus on individual rights and freedoms around the globe. China was trying to mobilize the support among countries for motto "harmony in diversity" with connotation of respecting not only different cultural fundamentals but also different socio-economic systems and different hierarchy of values opposing the prevailing focus on liberal and human rights order. In other words, China tried to use among others also this terrain to undermine the acceptance of the system of values that the West considers as universal and by infusing the idea of "harmony in diversity" was trying to enforce the principle of non-intervention into domestic affairs of countries that do respect different hierarchy of values where freedoms and individual rights do not take a top place.

In September 2005, Chinese President Hu Jintao delivered a major speech to a global audience at the United Nations. From the podium of the General Assembly, Hu introduced "Harmonious World" as a new concept of global politics, explaining that his goal was to "build a harmonious world of lasting peace and common prosperity." In this new world order, different civilizations would coexist in the global community, 
making "humanity more harmonious and our world more colorful."8 After Hu's announcement at the U.N., the notion of harmonious world was explained in two official documents: the "China's Peaceful Development Road" White Paper (2005), and Hu's "Report to the 17th Party Congress" (2007). ${ }^{9}$ Chinese attempts to infuse her motto into the UN as the highest representative international organization of the globe have ended unsuccessful but international community has clearly noticed that China was testing feasibility of her values on global scale.

\section{RESONANCE OF CHINA'S HISTORICAL MINDSET IN MODERN TIMES}

It is quite clear that China is not interested in becoming the "honorary member of the western club" in global arena but would like to have its own clout at least in regional if not global affairs promoting her own specific values. China is neither Western nor predominantly Christian, or even a child of the Enlightenment. The "Middle Kingdom" developed independently of Western philosophy and in modern history has recast foreign ideas including Marxism and Capitalism within its own templates of thoughts.

In recognition of China's growing influence in global politics the above is quite enough to justify the study of China's thinking patterns for better understanding of Chinese thoughts related to the world politics. Prof. Y.J.Choi, who has done comprehensive research on contrasting cultural concepts and thinking patterns of the West and the East, reviews Chinese and Western approaches to international relations in his book East and West: Rise of East Asia and fundamentals of international relations and argues that there will be three basic tendencies in $21^{\text {st }}$ century in global politics - co-evolution of Sino-American relations, Han Feizi/Machiavellian trap between order and disorder and the relevance of the Eastern pattern of international relations. ${ }^{10}$ This study does not support all three conclusions but shares the view that in search for global leadership in the $21^{\text {st }}$ century one of the most crucial factors in forming the new paradigm of international relations is a Chinese factor and the model of Sino-American relations.

\subsection{China's rejuvenation narratives of its unique hegemon behavior}

There are evident attempts of Chinese leaders to use philosophical and ancient intellectual reputation for defending China's attempt to return back to its past position after the century of humiliation that started by Opium Wars in the mid-19th century. China's endeavors are accompanied by highlighting certain narratives of her glorious past and idealized or half-idealized stories. It is curious the way in which Chinese leaders and public figures use ancient philosophical elites to empower, elevate or justify their controversial praxis and principles. It provides them with a mantle of legitimacy by continuing an apparent tradition already established a long time ago.

The research of Howard W. French in his book Everything Under the Heaven: How the Past Help Shape China's Push for Global Power and of John Pomfret's book The Beautiful Country and the Middle Kingdom provide highly precious contribution in this respect. They both illuminate conceptual thinking of Chinese leaders and continuation of China's historical mindset in modern times. This study shares some of their supportive

\footnotetext{
8 Hu Jintao (2006). Making an Effort to Build a Sustainable, Peaceful, and United Prosperous Har-monious World, Speech at the United Nations 60 Year Celebration. People's Daily, September 16, 2006, P. 1.

9 State Council, “China's Peaceful Development Road," Xinhua (Beijing), December 22, 2005; Hu Jintao, "Hold High the Great Banner of Socialism with Chinese Characteristics and Strive for New Victories in Building a Moderately Prosperous Society in All Respects: Report to the Seventeenth National Congress of the Communist Party of China on October 15, 2007," < http:/ / www. china.org.cn/english/congress/229611.htm>

${ }^{10}$ Choi, Y.J. (2015). East and West: Rise of east Asia and Fundamentals of Interantional Relations.
} 
observations for the purpose of highlighting parallels of Chinese ancient paradigms in Chinese current political behavior.

One can see these attempts in shaping Chinese President Xi Jinping's political agenda. On November 15 2012, the day Xi Jinping became General Secretary of the Chinese Communist Party, he called for "the great revival of the Chinese nation"11 that resonated deeply among today's Chinese and evoked historical memories of a time when China was a "center" of the world and received tributes from the rest of the world. Xi Jinping is not the first contemporary Chinese leader calling for national revival. Deng Xiaoping, Jiang Ziming and $\mathrm{Hu}$ Jintao embraced the theme of rejuvenating too, however, Xi Jinping features by the scale of efforts to achieve the goal of China's revival on international stage. He articulated new type of greatpower relations where China would enjoy the status of a global power in par with USA. He put in motion strategic initiative and crucial component of his foreign policy - a massive infrastructure plan One Belt One Road ${ }^{12}$, initiated new financing mechanism The Asian Infrastructure Investment Bank and revived centuries old claims to South China Sea as well as to other disputed areas. In other words, Xi Jinping rhetoric suggests that China today is simply reclaiming its proper place in the global order. This is done with the purpose of evoking historical memories of China's central position and implying that China in the past did not need the use of force to dominate the world but rather its cultural and technological advancement and virtues were those element that engendered deference from others.

It is hard to dispute basics of China as the preeminent power in Asia for over 1300 years starting from Tang dynasty in 618 to nearly the end of Qin dynasty in $1912 .{ }^{13}$ On the other side, the history reveals that rejuvenation narratives of current Chinese leaders regarding China's peaceful behavior are idealized or at least half-idealized. There is a significant gap between China's self-image and the geopolitical reality. ${ }^{14}$ The truth is that during the above mentioned period, China ruled the region under the principle of Chinese centrality "all under heaven" (tian xia) through a hierarchical order of relations in the form of tribute system paying by the neighbors. ${ }^{15}$ This system was based on the acknowledgement of cultural and political superiority of Chinese authority and kowtowing to Chinese Emperor to get privileges of trading with China. But there is also other side of this story proving that China's neighbors as Japan, Burma, Vietnam and Korea as well as some other countries were many times resisting this kind of relation arrangement, rejected Chinese rule overtly and fought against China's attempts of dominance. Chinese leaders mystify Chinese version when argue that China unlike other colonial powers managed its neighbors through kindness and virtue and so had little use for military power. These idealized versions of Chinese behavior are aimed at watering down concerns of the countries in the region and trying to promote the entrenched idea that China was a fundamentally different kind of hegemon.

Chinese Premier Li Keqiang in London in his speech claimed that "expansion is not in the Chinese DNA"16 and Xi Jinping stressed the same in his speech to Australian Parliament saying "countries that attempted to pursue their development goals with the use of force invariable failed ... This is what history

\footnotetext{
${ }^{11}$ Full Text: China's New Party Xi Jinping Speech. http:/ / www.bbc.com/news/world-asia-china-20338586

12 South China Morning Post (2016). Xi Jinping's One Belt, One Road strategy is showing a Way toi a New World Order. 13th

December 2016

${ }^{13}$ Callham, Willilam A. (2013). China Dreams. 20 Visionas of the Future. Oxford University Press. Liu MIngfu (2010).

The China Dream. P.57

${ }^{14}$ Elizabeth, C. (2017). Economy. History With Chinese Characterstics: How China's Imagined Past Shapes Its Present.

Foreign Affairs (July/ August 2017). P.142

15 Zhang Feng (2010). The Tianxia System: World Order in Chinese Utopia. China Heritage Quaterly (21.3.2010).

${ }^{16}$ Li Keqiang (2014). China Loves Peace says Premier despite Regional Disputes. Space Daily. 18th June 2014.
} 
teaches us. China is dedicated to upholding peace."17 In reality, Chinese dynasties invaded lands of today's Vietnam and Korea many times, tried to bar local traditions, forced to wear Chinese dress, confiscated literature. China has also tried to portray Famous Chinese fleet Admiral Zheng He (1371-1433 or 1435), explorer, diplomat, during China's early Ming dynasty, as a peaceful man whose mission was to „spread „knowledge of the emperor's majesty and virtue“. Actually, Zheng $\mathrm{He}$ was an agent of Chinese expansionism and though his expeditions were not designed to secure territories, they were intended to ensure subordination of the nations to China, the demand that he would enforce with military power if necessary. Among all these attempts, one of the top Chinese strategists Yan Xuetong openly argues that China's world order is superior because it involves "voluntary submission" to an international power that "owns the world". In addition to these idealized narratives, Chinese leaders try to use intellectual reputation of ancient Chinese thinkers to justify their domestic policies. Xi Jinping quoted several times Han Feizi's dictum "when those who uphold the law are strong, the state is strong. When they are weak, the state is weak" to justify his tough anti-corruption campaign, his more authoritarian style of government and to defend his actions per sake of his authority.

This is not to question Chinese philosophical framework that was supporting moderation and harmonization of relationship inside society as well as with outside world. This concept has definitely impacted thinking inclination of Chinese mind. On the other side the history shows that the real policy was many times far from China's philosophical background and that China has not lacked expansionist and colonial impulses and like other imperial powers used force in the service of territorial expansion. When China's management of situation and securing influence in neighboring territories has failed, China resorted to the force. The claims of Chinese officials that China is different from other powers, non-colonial, noninterventionist but peaceful is a purposeful exercise to revitalize ideas of China's uniqueness as well as to assuage and appease concerns of its neighbors about its growing military strength.

Demythologizing China's past brings an added value to political debate over the nature of China's rise and associated challenges. While Beijing says that China would peacefully rise as a responsible power to build a harmonious world within the present international system, China in parallel shows the thirst for the world system based on Chinese traditions at least in the regional framework.

\section{GROWTH OF CHINA AS A RISE OF DIFFERENT CONCEPT OF VALUES}

The influence of traditional Chinese values on the international community has not been as pronounced as the influence of modern Western values. As China rapidly moves to center stage in world politics, the question of this emerging power's international purpose and foreign policy is becoming an important issue. Chinese government's official line is often very vague on questions what is China's international mission, how might it realize its agenda and whether it has a blueprint for action. On the other side, China's domestic intellectual elite have been advancing a diverse set of arguments about China's future international role. Intellectual power of these emerging views influences, to varying degrees, China's policy choices and deserves serious attention.

This study brings two influential thinking trends in China's intellectual circles - Liu Mingfu, senior colonel in the People's Liberation Army who is championing military strength of China as the tool of deterrence and Zhao Tingyang, distinguished academician who is upholding soft approach by implementing old China paradigm of harmonious world.

17 Xi Jinping speech at Federal Parliament of Australia 17 November 2014. 
Zhao Tingyang is an influential Chinese thinker, Professor at the Institute of Philosophy at the Chinese Academy of Social Sciences in Beijing. He elaborates on applicability of Chinese ancient concept to modern times. He first gained attention for his 1993 book On possible lives: a theory of happiness and justice and he vaulted into super-stardom with his 2005 book The All-Under-Heaven System: An Introduction to the Philosophy of a World Institution. His appropriation of the "tianxia" idea (all under heaven) has been widely discussed, positively and negatively, both within philosophy and international circles. Believing that China can become a new kind of great power - one that is responsible for the whole world, but in a different way from historical empires - Zhao aims to create new concepts about the world and world institutions by promoting the idea of tianxia as the pivotal unit in analyzing world politics. He finds many inadequacies in existing Western theories of international relations, not least their exclusive emphasis on the nation-state as the unit of analysis. In his view, the world today is still a non-world, and the real problem we face is not so-called failed states, but a failed world. He criticizes Western theories for contributing to this failed world with their emphasis on the nation-state, and asserts that China's tianxia theory, which borrows its key ingredients from ancient Chinese thought, can remedy this critical deficiency. He argues that tianxia theory offers an alternative, far better model of a future world order that takes into account the interests of the entire world, whatever its constituent elements. ${ }^{18}$ Zhao's insistence on the need to "rethink China" means to re-think the significance of China, Chinese culture, and Chinese philosophy, and to do so from China's standpoint. According to Zhao the historical significance of "rethinking China" lies in striving to restore China's own ability to think, so that China once again reestablishes its own frameworks of thought and fundamental concepts, once again creates its own worldview, values, and methodology, and ... reflects on China's future ... and on China's role and responsibilities in the world. He contrasts "rethinking" China with "discussing China," in which China is the object of analysis but not necessarily the active subject undertaking the analysis. ${ }^{19}$ Addressing Confucianism, he urges that Confucianism should not be understood as "finished" or complete and it needs to dynamically respond to challenges and to move from "local knowledge" to "universal knowledge." Zhao Tingyang thoughts are representing strong thinking intellectual wave inside China and his popularity proves the strong feeling among Chinese intellectual circles to bring China's own worldviews and values to the world institutions and international relations.

Liu Mingfu's The China Dream: The Great Power Thinking and Strategic Positioning of China in the Post-American Age generated huge local and global interest when it was published in 2010. Liu is a senior colonel in the People's Liberation Army (PLA) at China's National Defense University (NDU), so his work could reflect some portion of the military's views. In contrast to Beijing's policies of peaceful rise and harmonious world, Liu tells that to guard its economic rise China needs to have a "military rise" to contest American hegemony. He warns that China should not strive to become an economic superpower like Japan, which would make China a "plump lamb" that risked being gobbled up by military rivals. ${ }^{20}$ To be a strong nation, a wealthy country needs to convert its economic success into military power. Rather than follow Deng Xiaoping's peace and development policy of "beating swords into ploughshares", Liu tells that China needs to "turn some 'money bags' into 'ammunition belts." Liu argues that The China Dream does not see conflict with the U.S. as inevitable. China's military rise is not to attack America, but to make sure that China is not attacked by America. Liu is using the logic of deterrence to stress that China must seek peace through strength: its peaceful rise to great power status must include a military rise with Chinese characteristics that is defensive,

18 Zhang Feng (2010). The Tianxia System: World Order in Chinese Utopia. China Heritage Quaterly

${ }_{19}$ Zhao Tingyang on Rethinkg China. Warp, Weft and Way. Chinese and Comparative Philosophy

20 William A. Callham (2013). China Dreams. 20 Visions of the Future. Oxford University Press. 
peaceful, limited, necessary, important, and urgent. The goal of this peaceful military rise is "to grasp the strategic opportunity for strengthening the military" in order to surpass America to become the world's number one military power. ${ }^{21} \mathrm{Liu}$ himself stresses that his book is not a reflection of official policy and that it was written for a mass-market audience and published by a commercial press but the truth is that it reflects a strong tide of Chinese thought.

Historical sentiments of China's past centrality are strongly present in China's public opinion. China's behavior is slowly but aggressively "showing arms" in making her own space in the region with self-asserting and growing influence. China's rejection of the decision by the Permanent Court of Arbitration which found the claim to all the territories in the South China Sea within the so called "nine-dash line" to be without merit, exemplifies China's traditional sense that its great power status allows it to ignore international law. China's economic retaliation against Seoul over the deployment of the U.S.-led Terminal High Altitude Area Defense (THAAD) system in 2016/17 is another example of China's behavior to its neighbors. China sent to South Korea a clear message she does not care about her national security concerns facing North Korean nuclear threat but will penalize her as well as other neighbors if their behavior does not match China's security architecture that is viewed predominantly through prism of competition with USA. In addition to this China is trying to undertake initiatives to forge its economic dominance in the region through regional institutions under her dominance such as Asian Infrastructure Investment Bank or pan-Asian Regional Comprehensive Economic Partnership with the aim to limit US influence.

To put it in a nutshell, China's behavior in the region echoes China's imperial tribute system of the past messaging to neighbors that in order to ensure prosperity China expects deference but it is a small price to pay for a stability and co-prosperity. ${ }^{22} \mathrm{On}$ global front China is spreading its cultural values by setting up government-funded cultural centers called Confucius Institutes around the world as well as broadcasting state-run English-language radio and TV programs.

\section{SINO-AMERICAN RELATIONS AS A KEY FACTOR OF FUTURE GLOBAL LEADERSHIP}

For international relations as a field of study there is a clear implication that it can no longer be assumed that the world will continue to operate only in accordance with Western constructs of thought. China as the fastest rising global power has already become a peer to the USA, even if it has not achieved military or economic parity.

It is generally acknowledged that Sino-American relations will be key influential factor for peace and stability in the $21^{\text {st }}$ century. China's re-emergence as a world economic power raises important questions about what can be learnt from its previous rise and fall and about external and internal threats confronting the emerging economic superpower for the immediate future. ${ }^{23}$ In this context, understanding the background of thinking patterns of China's leaders and influential intellectuals, as it was indicated above, contributes to better perception of the dynamics of China - USA relationships as well as the formation of the future global leadership.

\footnotetext{
${ }^{21}$ Liu Mingfu (2010). The China Dream. P.58. See also Chris Buckley: China PLA Officer Urges Challenging U.S. Dominance. Reuters. 1 March 2010

22 Elizabeth C. Economy (2017). History With Chinese Characteristics. How China's Imegined past Shapes Its Present. Foriegn Affairs. July/August 2017. P.142

23 Prof. James Petras (7.3.2012). China: Rise, Fall and Re-Emergence as a Global Power
} 
Sino-US relations in $21^{\text {st }}$ century face many challenges with regard of rebalancing power including military, economic, cultural issues that are manifested in numerous areas of bilateral and multilateral relationships. Based on diverging cultural fundamentals between the East and the West, one can see in these challenges and in addition to the power "battle", a common denominator - Chinese efforts to spread her influence and her hierarchy of values at least in the surrounding region and to get more weight in global affairs. These attempts are going on several fronts of Chinese foreign policy activities.

The broader picture of China's rise to global affairs architecture shows that the major efforts are focused on incorporation China into global institutional system. China calculates that since the global economic and environmental problems cannot be solved without her participation, the only way to make existing institutions functional is to make them more representative. It can be seen as a kind of tradeoff between liberalism and effectiveness of international institutions. On global arena, the more Western-dominated institutions, the more likely they will keep a liberal bias but less representative pattern and probably less functional. Different cultural fundamentals will make the rapprochement between China and USA more difficult due to the fact that China has not subscribed to the liberal norms of the countries that established the world's existing institutions. ${ }^{24}$ This resistance stems not just form China' s own illiberal nature but also from her distinctly noninterventionist worldview supporting its agenda of claims to Taiwan. As a result it hinders China - USA cooperation in many fields and regions including such "hot spots" as Iraq and Syria. Another issue represents China's strategy of portfolio diversification whereby Beijing expands it institutional options and actively supports parallel structures such as BRICS or Asian Infrastructure Investment Bank aimed at replacing US world dominance. This is accompanied by China's growing self-assertiveness, manifested in the mode of "super power" behavior in the region, as has been shown by China's refusal to accept the decision of the Permanent Court of Arbitration regarding her territorial claims in the South China Sea. Such kind of approach has been signaling China's determination to change the status quo in the region and ignorance of international law. The serious challenge to the Western liberal system represents Beijing's expectation that China's growth and her increased role in global affairs will reduce the influence of small democracies that will put them on the sideline of the world politics. This would be reflected in a kind of marginalization of the neighbors and small countries resembling their vassal position in the past.

There are many predictions and prescriptions for future Sino-China model of relations. What is quite evident in today's Sino-American dynamics is the tendency of changing status quo and the ongoing shift of the power balance in East Asia. Beijing seeks to supplant USA in the region and USA, on the other side, tries to keep its influence as a balancing power. It is possible to sympathize with China's desire for greater influence in its historical geographical surroundings and to understand its feelings of a certain humiliation that China suffered over century but it is hard to agree with attempts of implanting to the region China's harmonious ideas based on hierarchical structure.

Historical experience of Sino - American relations indicate that the best way to go forward in future relations of these two giants is what USA have already tried in the recent period - engagement instead of confrontation. After recounting China's domestic and social challenges and US economic and cultural strengths the USA can hold their position and China can get more regional dominance. The reality is that the usual strategy will unlikely be sufficient for managing increasingly powerful and illiberal China but the best part forward would be to acknowledge the importance of cooperation between USA and China, adopting a greater element of reciprocity in bilateral relations, opening doors to China's membership into

\footnotetext{
${ }^{24}$ Mazarr, Michael J. (2017). The Once and Future Order. What Comes After Hegemony? Foreign Affairs.
} January/February 2017. P. 35 
international system and urging China to become a responsible stakeholder in global affairs instead of Beijing's tendency to "free-ride" on the world security and stability provided by USA in Asia and the world. ${ }^{25}$ China's pragmatic self-interest, in this context, has been among others manifested after $9 / 11$ in the "bystander position" to American projection of power across the Muslim world.

Rhythms and patterns of Chinese history show that China is able to give a time on the path to attain her expectations with regard to her global role and to hold a "waiting position" for a long time of period when it is needed. Beijing also retains its characteristic willingness and ability to adjust to changes in alignments of power without passing a moral judgment ${ }^{26}$ that is reflecting China's highly pragmatic orientation. Henry Kissinger's remarks on China's statesmanship in his book "On China" are putting this issue in the following way:

In general, Chinese statesmanship exhibits a tendency to view the entire strategic landscape as a part of a single whole good and evil, near and far, strength and weakness, past and future all interrelated. In contrast to the Western approach of treating history as a process of modernity achieving a series of absolute victories over evil and backwardness, the traditional Chinese view of history emphasized a cyclical process of decay and rectification, in which nature and the world can be understood but not completely mastered. The best that can be accomplished is to grow into harmony with it. Strategy and statecraft become means of "combative coexistence" with opponents. The goal is to manewver them into weakness while building up one's own "shi", or strategic position. ${ }^{27}$

China is self-confident in its exceptional cultural background and though it does not proselytize or claim that its institutions "are relevant to the whole world," yet it tends to grade at least other states in the region, as various levels of derivatives, based on their approximation to Chinese cultural and political forms. ${ }^{28}$ On this backdrop, China behaves like a regional hegemon with ambitions to be gradually a hegemon in larger scale. At the current stage, the same as USA tries to manifest its destiny through its missionary role stressing American exceptionalism, China is doing this on regional level and is testing avenues on the global front.

\section{CONCLUSION}

Differences between Chinese and Western ancient thinking paradigms in dealing with neighbors and outside world are evident. Understanding China's historical patterns of interaction with outside world provides an added value to the perceptions of China's future role in global affairs. The study is based on assumption that ancient habits of mind and of statecraft have been so deeply ingrained in Chinese minds that they still today shape their political views.

The paper introduced relevant philosophic frameworks that formed the basic Eastern and Western worldviews and major concepts through which both cultures looked at outside world. Diverging concepts of perceptions of opposite poles, different focus on circumstances versus opponents, management of situations versus conflict solutions, different application of the Golden rule and the concepts of harmony and hierarchy have subscribed into different approaches of both cultures when dealing with international issues. The East focused more on upholding harmonious relationships and managing situations trying to

\footnotetext{
${ }^{26}$ Kissinger, H. (2011). On China

${ }^{27}$ Kissinger, Henry (2011). On China. P. 22-23

28 Kakutani Michiko (May 9, 2011). An Insider Views China, Past and Future http://www.nytimes.com/2011/05/10/books/on-china-by-henry-kissinger-review.html
} 
prevent the outbursts of conflicts while the West aimed at looking for effective solutions of imminent conflicts. Chinese ideal of harmonious international order was based on hierarchical system with China position at the top and assimilation of opponents and enemies through cultural dominance. Western concept was based on conflict solutions, securing the peace through winning the conflicts and annihilation of enemies while after the Treaty of Westphalia the model of respecting territorial integrity and sovereignty started to prevail. There are similarities and differences in ancient minds of both cultures regarding their approach to the outside world. The study brings in this way, as samples, the comparison of realpolitik concepts of Chinese Han Fei and Italian Niccolo Machiavelli as well as war strategies of Chinese Sun Tzu and Prussian General Clausewitz. The paper analyzes the relevancy of Eastern ancient concept of harmony into the $21^{\text {st }}$ century and clearly concludes that the idea of harmony-hierarchy system has no applicability in modern times. What is applicable among Eastern heritage in the context of international domain in the 21st century is the Eastern mind inclination to perceive the problems in broad context, attitude of moderation, patience with time and the strong focus on managing situations aimed at preventing conflic ts to burst out. That is matching the modern Western concepts of preventive diplomacy and post-conflict management. In projection of the future global leadership the study focuses on Sino-American relations as a key factor in forming global leadership as well as on manifestations of embedded Chinese thinking habits in China's trajectory of growth. The paper highlights that Chinese ancient thinking inclinations are present among Chinese intellectuals as well as Chinese leaders and there are attempts to idealize China's past for raising China's self-assertiveness as a hegemon with unique features and with the purpose of returning China back to the dominant position at least in the region. In broader context the study comes with the conclusion that Sino-American relationship is a complex issue through which one can see not only the power politics but also the "battle" for the future orientation of the world system of values.

\section{REFERENCES}

Ando (2008). Clausewitz vs Sun Tzu. Past Tense. Retrieved from https://answersinhistory.wordpress.com/2008/03/13/clausewitz-vs-sun-tzu/

BBC (2012). Full text: China's New Party Xijinping Speech. Retrieved from http:/ / www.bbc.com/news/world-asia-china20338586

Buckley, C. (2010). China PLA officer urges challenging US dominance. Reuters, March, 1.

Callahan, W. A. (2013). China dreams: 20 visions of the future. Oxford University Press. ISBN 978-0190235239.

Choi, Y.J. (2015). East and West: Rise of East Asia and Fundamentals of International Relations. Charleston 03 May 2016. ISBN 978-1519562944

Clausewitz.com (2016). Clausewitz, On War, excerpts relating to term "Center[s] of Gravity. Retrieved from https://www.clausewitz.com/opencourseware/Clausewitz-COGexcerpts.htm

Dao De Jing (2015). A Philosophical Translation by Roger Ames (Author), David Hall (Author) of Lao Zi (Author). The Random House Publishing Group. ISBN 0-345-44419-1

Diamond, J. (1999). Guns, Germs, and Steel: The Fates of Human Societies (New York, 1997). Gale Stokes included this Pulitzer Prize-winning book in a review essay, "The Fates of Human Societies: A Review of Recent Macrobistories," AHR, 106, 508-25. ISBN 978-0393317558

Economy, E. C. (2017). History with Chinese Characteristics: How China's Imagined Past Shapes Its Present. Foreign Aff., 96, 141-148.

Fei. H. \& Machiavelli (2102). Non-Moral Political Outlook. Research Papers Center. Post Time 2012. Retrieved from http://thediplomat.com/2015/01/why-we-should-study-chinas-machiavelli/

French, H. W. (2017). Everything Under the Heavens: How the Past Helps Shape China's Push for Global Power. Knopf. ISBN 978-0385353328 
Gady, F. S. (2015). Why should we study China's Machiavelli. The Diplomat. Retrieved from http://thediplomat.com/2015/01/why-we-should-study-chinas-machiavelli/

Hu Jintao (2006). Making an Effort to Build a Sustainable, Peaceful, and United Prosperous Harmonious World, Speech at the United Nations 60 Year Celebration. Renmin Ribao [People's Daily], September 16, 2006

Jacques, M. (2009). When China rules the world: The end of the western world and the birth of a new global order. Penguin. ISBN 978-0143118008

Kakutani, M. (2011). An insider views China, past and future. New York Times, 9. Retrieved from http://www.nytimes.com/2011/05/10/books/on-china-by-henry-kissinger-review.html

Keqiang, Li (2014). China Loves Peace says Premier despite Regional Disputes. Space Daily. 18th June 2014. Retrieved from

http://www.spacedaily.com/reports/China loves peace says premier despite regional disputes 999.html

Kissinger, H., \& Hormann, N. (2011). On China (p. 88). New York: Penguin Press. ISBN 978-0143121312

Kynge, J. (2007). China Shakes the World: A Titan's Rise and Troubled Future--and the Challengefor America. Houghton Mifflin Harcourt. ISBN 978-0-618-70564-1.

Mazarr, M. J. (2017). The Once and Future Order: What Comes after Hegemony. Foreign Aff., 96, 25-40.

Petras, J. (2015). China: Rise, fall and re-emergence as a global power. Global Research.

Pomfret, J. (2016). The Beautiful Country and the Middle Kingdom: America and China, 1776 to the Present. Macmillan. ISBN 978-0805092509

South China Morning Post (2016). Xi Jinping's One Belt, One Road strategy is showing a Way to a New World Order. 13th December 2016. Retrieved from http://www.scmp.com/comment/insight-opinion/article/2054143/xijinpings-one-belt-one-road-strategy-showing-way-new-world

State Council (2005). China’s Peaceful Development Road, Xinhua (Beijing), December 22, 2005; Hu Jintao, “Hold High the Great Banner of Socialism with Chinese Characteristics and Strive for New Victories in Building a Moderately Prosperous Society in All Respects: Report to the Seventeenth National Congress of the Communist Party of China on October 15, 2007," Retrieved from http://www.china.org.cn/english/congress/229611.htm

Tzu, S. (2005). The art of war. Shambhala Publications.

Warp, Weft and Way (2010). Zhao Tingyang on Rethinking China. Chinese and Comparative Philosophy. Retrieved from http://warpweftandway.com/zhao-tingyang-on-rethinking-china/

YouTube (2104). Xi Jinping speech at Federal Parliament of Australia 17 November 2014. Retrieved from https:/ / www.youtube.com/watch?v $=$ Qv6ZmGBlxqU

Zhang, F. (2010). The Tianxia system: world order in a Chinese Utopia. Global Asia, 4(4), 108-112.

Zhang, L. (2013). China's Traditional Values and Modern Foreign Policy. January, 15. 